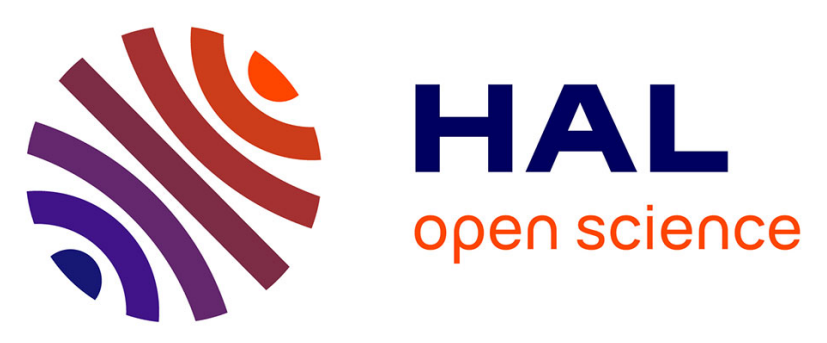

\title{
Characterization of adenosine A 2 receptors of peripheral blood mononuclear cells of patients with fibromuscular dysplasia
}

François Silhol, Marion Marlinge, Claire Guiol, Mohamed Chefrour, Patrick

Mace, Christine Criado, Nathalie Kipson, Bernard Vaisse, Donato Vairo, Gabrielle Sarlon, et al.

\section{To cite this version:}

François Silhol, Marion Marlinge, Claire Guiol, Mohamed Chefrour, Patrick Mace, et al.. Characterization of adenosine A 2 receptors of peripheral blood mononuclear cells of patients with fibromuscular dysplasia. Hypertension Research, 2020, 10.1038/s41440-019-0379-3 . hal-02569516

\author{
HAL Id: hal-02569516 \\ https://hal.science/hal-02569516
}

Submitted on 11 May 2020

HAL is a multi-disciplinary open access archive for the deposit and dissemination of scientific research documents, whether they are published or not. The documents may come from teaching and research institutions in France or abroad, or from public or private research centers.
L'archive ouverte pluridisciplinaire HAL, est destinée au dépôt et à la diffusion de documents scientifiques de niveau recherche, publiés ou non, émanant des établissements d'enseignement et de recherche français ou étrangers, des laboratoires publics ou privés. 


\section{Characterization of adenosine $A_{2}$ receptors of peripheral blood mononuclear cells of patients with fibromuscular dysplasia}

François SILHOL ${ }^{1 *}$, Marion MARLINGE ${ }^{2,3^{*}}$, Claire GUIOL ${ }^{2 *}$, Mohamed CHEFROUR $^{3}$, Patrick MACE ${ }^{3}$, Christine CRIADO ${ }^{2}$, Nathalie KIPSON $^{2}$, Bernard VAISSE $^{1}$, Donato VAIRO $^{2}$, Gabrielle SARLON ${ }^{1}$, Jean RUF $^{2}$, Anne DONNET $^{4}$, Laurie BRUZZESE ${ }^{2}$, Giovanna MOTTOLA ${ }^{2}$, Régis GUIEU ${ }^{2,3,4^{*}}$, Emmanuel FENOUILLET $^{2,5^{*}}$

1 Hypertension Department, Pôle Cardio-Vasculaire, Hôpital de la Timone 264 Avenue Saint-Pierre 13385 Marseille cedex 05

2 Aix Marseille Université, INSERM, INRA, C2VN

3 Laboratory of Biochemistry, Hôpital de la Timone

4 Chronic Pain and Headache Centre, Hôpital de la Timone

5 Institut des Sciences Biologiques, CNRS, 75016 Paris, France

* These authors contribute equally to the work

Correspondence to: François Silhol, Hypertension Department, Pôle Cardio-Vasculaire, Hôpital de la Timone, 264 Avenue Saint-Pierre, 13385 Marseille cedex 05. E-mail: francois.silhol@ap-hm.fr 
Fibromuscular dysplasia (FMD) is a non-atherosclerotic, non-inflammatory vascular disease characterized by unexplained systemic hypertension under the age of 35, migraine-like headache, epigastric or cervical bruit, arterial stenosis, aneurysm rupture, intracranial/renal infarction, renal damage and stroke ${ }^{1,2}$.

Although the gold standard for the diagnosis remains catheter angiography, biological markers would be helpful as the delay from first symptom to diagnosis is long. It is of note that most patients are females ${ }^{1}$, which is in agreement with high expression of progesterone receptors in renovascular FMD $^{3}$.

Adenosine, an ATP derivative, may be implicated in FMD pathophysiology. Adenosine exerts its effects via its membrane receptors: $A_{1} R, A_{2 A} R, A_{2 B} R$, and $A_{3} R^{4}$. While $A_{1} R$ and $A_{3} R$ control heart rhythm and the adaptive response to ischemia-reperfusion, respectively, $A_{2 A} R$ and $A_{2 B} R$ impact blood flow $^{4}$. Although acute release of adenosine improves vascular blood flow, and hence is cardiovascular protective ${ }^{4}$, chronic exposure to high adenosine plasma level (APL) has deleterious effects especially via $\mathrm{A}_{2 \mathrm{~B}} \mathrm{R}$ activation that promotes vascular fibrosis ${ }^{5,6}$.

We hypothesized therefore that changes in APL and expression of $\mathrm{A}_{2 \mathrm{~A}} \mathrm{R}$ and $\mathrm{A}_{2 \mathrm{~B}} \mathrm{R}$ are associated with FMD.

\section{Patients}

Adult patients with multifocal FMD (diagnosed using CT scan or duplex ultrasound) were included according to current criteria ${ }^{7}$. Common migraine diagnosis was in accordance with the ICHD-3 classification. Patients with essential hypertension (EH) were also included. Control group, matched for age and sex, was recruited among the medical staff.

\section{APL measurement}

Blood samples were collected and processed using tubes containing stop solution and APL was measured by liquid chromatography-tandem mass spectrometry ${ }^{8}$ (Shimadzu UFLC XR, Marne-laVallée, F).

\section{$A_{2}$ receptors production by peripheral blood mononuclear cells (PBMCs)}

PBMCs were chosen because the pharmacological profile of adenosine receptors expressed at their surface mirrors that of their counterparts associated with cardiovascular tissues ${ }^{8}$. PBMCs were isolated from blood using the Vacutainer-CPT system (Becton-Dickinson, Franklin-Lakes, NJ). $\mathrm{A}_{2 \mathrm{~A}} \mathrm{R}$ production was assessed by Western blot and results were expressed in arbitrary units (AU) according 
to a procedure previously validated ${ }^{8}$. $\mathrm{A}_{2 \mathrm{~B}} \mathrm{R}$ production was similarly addressed except the use of a commercial antibody (Abcam ${ }^{\circledR}$, Cambridge, UK).

\section{Statistical analysis}

Quantitative variables are reported as mean \pm standard deviation (SD) or median and interquartile range (IQR), and qualitative variables as numbers and percentages. A variance analysis (ANOVA two ways) was used for intergroup comparisons. Two-sided tests were performed and P-value $<0.05$ was considered as significant.

\section{Patients}

Clinical characteristics are given (Table 1). Among the 24 FMD patients, 14 (58\%) had headaches and $6(25 \%)$ typical migraine crisis ("FMD with migraine" patients thereafter). Twenty-one FMD patients (87\%) were treated for hypertension (SBP: mean[range]: 128[115-140]mmHg; DBP:78[63-90]mmHg) at time of blood collection. The EH patients were also treated for hypertension (SBP: 133[118-149] mmHg; DBP:70[54-85] mmHg).

\section{$A P L$}

APL was high in FMD patients (Fig.1, panel A; FMD vs controls: $2.68 \pm 0.95$ vs $0.59 \pm 0.13 \mu \mathrm{M}$; $\mathrm{p}<0.01$ ) but was not affected by the presence of associated migraine (FMD vs FMD with migraine: $2.68 \pm 0.95$ vs $2.70 \pm 1.30 \mu \mathrm{M} ; \mathrm{p}=0.7)$. APL was higher in FMD with migraine vs migraine patients $(2.70 \pm 1.30$ vs $0.56 \pm 0.14 \mu \mathrm{M} ; \mathrm{p}<0.001)$. APL was similar in migraine patients and controls $(0.56 \pm 0.14$ vs $0.59 \pm 0.13 \mu \mathrm{M} ; \mathrm{p}>0.05)$ and higher in $\mathrm{EH}$ patients vs controls $(0.82 \pm 0.15$ vs $0.59 \pm 0.13 \mu \mathrm{M} ; \mathrm{p}=$ $0.0015)$.

\section{Receptor Production}

$\mathrm{A}_{2 \mathrm{~A}} \mathrm{R}$ production was affected neither by FMD (Fig.1, panels B \& C; FMD vs controls: $1.23 \pm 0.15$ vs $1.19 \pm 0.08 \mathrm{AU} ; \mathrm{p}=0.5$ ) nor by the presence of associated migraine (FMD vs FMD with migraine: $1.23 \pm 0.15$ vs $1.27 \pm 0.12 \mathrm{AU} ; \mathrm{p}=0.5)$. $\mathrm{A}_{2 \mathrm{~A}} \mathrm{R}$ production was also affected neither by migraine nor by hypertension (migraine: $1.16 \pm 0.12 \mathrm{AU}$; EH: $1.27 \pm 0.18 \mathrm{AU}$; controls: $1.19 \pm 0.08 \mathrm{AU}$; $\mathrm{p}=0.29$ and 0.86 , respectively).

$\mathrm{A}_{2 \mathrm{~B}} \mathrm{R}$ expression was high in FMD patients (Fig.1, panel B \& C; FMD vs controls: $2.46 \pm 0.77$ vs $1.20 \pm 0.12 \mathrm{AU} ; \mathrm{p}<0.001)$ but was not affected by the presence of associated migraine (FMD vs FMD with migraine: $2.46 \pm 0.77$ vs $2.58 \pm 0.97 \mathrm{AU} ; \mathrm{p}=0.9)$. $\mathrm{A}_{2 \mathrm{~B}} \mathrm{R}$ production was higher in FMD with migraine vs migraine patients (FMD with migraine vs migraine: $2.58 \pm 0.97$ vs $1.32 \pm 0.25 \mathrm{AU}$; 
$\mathrm{p}<0.001)$. Finally $\mathrm{A}_{2 \mathrm{~B}} \mathrm{R}$ production did not differ in migraine patients or $\mathrm{EH}$ patients vs controls (migraine: $1.32 \pm 0.25 \mathrm{AU}$; EH: $1.27 \pm 0.16 \mathrm{AU}$; controls: $1.20 \pm 0.12 \mathrm{AU} ; \mathrm{p}=0.2$ and 0.32 , respectively).

We show here that FMD patients have high APL and high $\mathrm{A}_{2 \mathrm{~B}} \mathrm{R}$ production, irrespective of the presence of migraine.

Various reports are consistent with a role of $\mathrm{A}_{2 \mathrm{~B}} \mathrm{R}$ in the maintenance/progression of FMD: although upregulation of $\mathrm{A}_{2 \mathrm{~B}} \mathrm{R}$ protects against acute vascular injury via TNF-alpha in an animal model ${ }^{9}$, activation of $\mathrm{A}_{2 \mathrm{~B}} \mathrm{R}$ leads to vascular smooth cell apoptosis ${ }^{6}$ and fibrosis ${ }^{5}$. This supports a role of $\mathrm{A}_{2 \mathrm{~B}} \mathrm{R}$ activation in the maintenance/progression of FMD. Interestingly, $\mathrm{A}_{2 \mathrm{~B}} \mathrm{R}$ has low affinity for adenosine ${ }^{4}$ and is activated only in case of high APL that are in the range of the levels found here in FMD patients.

We found no significant difference in $\mathrm{A}_{2 \mathrm{~A}} \mathrm{R}$ expression in FMD patients as well as in migraine patients compared with controls. $\mathrm{A}_{2 \mathrm{~A}} \mathrm{R}$ is highly expressed in patients with essential hypertension that normalized after treatment using doxazosin but not using propanolo ${ }^{10}$. Here, despite a context of hypertension, no significant difference in $\mathrm{A}_{2 \mathrm{~A}} \mathrm{R}$ expression was found between FMD with associated hypertension and controls” probably because of the normotensive status of patients at the sampling time.

Whether FMD is a rare or common disease is subject of debate, probably because of the difficulty of diagnosis and the time delay from onset to diagnosis. Indeed, the mean age for first symptom is around 47 years while the mean age at diagnosis is 52 years $^{1}$. FMD may affect every arterial bed but it mostly affects the renal and extracranial carotid as well as vertebral arteries ${ }^{1}$. Thus, FMD is rather a systemic disease. It is therefore not surprising that FMD is associated with systemic adenosinergic abnormalities as observed here using PBMCs.

Our results indicate that FMD is associated with high $\mathrm{A}_{2 \mathrm{~B}} \mathrm{R}$ expression and high APL, irrespective of the presence of migraine-like headache. The mechanistic role of $A_{2 B} R$ in FMD needs study. Measurement of $\mathrm{A}_{2 \mathrm{~B}} \mathrm{R}$ production by using a simple blood collection may represent a valuable biological marker of FMD and a help in FMD diagnosis.

Key words: fibromuscular dysplasia, migraine, adenosine $\mathrm{A}_{2}$ receptors, adenosine 


\section{Conflict of interest: None}

\section{References:}

1. Olin JW, Froehlich J, Gu X, Bacharach JM, Eagle K, Gray BH et al. The united states registry for fibromuscular dysplasia: results in the first 447 patients. Circulation 2012; 125:3182-90.

2. van Twist DJL, de Leeuw PW, Kroon AA. Renal artery fibromuscular dysplasia and its effect on the kidney. Hypertens Res. 2018; 41:639-48.

3. Silhol F, Sarlon-Bartoli G, Daniel L, Bartoli JM, Cohen S, Lepidi H et al. Intranuclear expression of progesterone receptors in smooth muscle cells of renovascular fibromuscular dysplasia: a pilot study. Ann Vasc Surg 2015; 29:830-5.

4. Burnstock G. Purinergic signaling in the cardiovascular system. Circ Res 2017; 120:207-28.

5. Borea PA, Gessi S, Merighi S, Vincenzi F, Varani K. Pharmacology of adenosine receptors: The State of the Art. Physiol Rev 2018; 98:1591-1625.

6. Peyot ML, Gadeau AP, Dandré F, Belloc I, Dupuch F, Desgranges C. Extracellular adenosine induces apoptosis of human arterial smooth muscle cells via A(2b)-purinoceptor. Circ Res 2000; 86:76-85.

7. Slovut DP, Olin JW. Fibromuscular dysplasia. N Eng J Med 2004; 350: 1862-71.

8. Gariboldi V, Vairo D, Guieu R, Marlingue M, Ravis E, Lagier D et al. Expressions of adenosine A2A receptors in coronary arteries and peripheral blood mononuclear cells are correlated in coronary artery disease patients. Int J Cardiol 2017; 230:427-31.

9. Yang D, Koupenova M, McCrann DJ, Kopeikina KJ, Kagan HM, Schreiber BM, Ravid K. The A2b adenosine receptor protects against vascular injury. Proc Natl Acad Sci U S A 2008; 105:792-6.

10. Varani K, Manfredini R, Iannotta V, Pancaldi C, Cattabriga E, Uluoglu C et al. Effects of doxazosin and propranolol on A2A adenosine receptorsin essential hypertension. Hypertension 2002; 40:909-13. 


\section{Figure 1 legend:}

Adenosine plasma level (Panel A) and $\mathrm{A}_{2 \mathrm{~A}^{-}}$or $\mathrm{A}_{2 \mathrm{~B}}$-receptor expression (Panel B) in patients. a: Whole FMD patient population; $b$ : FMD without migraine-like headache; c: migraine patients; d: FMD with migraine-like headache; e: hypertensive patients (hypertension); f: controls. Examples of Western blot of $\mathrm{A}_{2 \mathrm{~A}^{-}}$(Top) and $\mathrm{A}_{2 \mathrm{~B}^{-}}$(Bottom) receptor production by peripheral blood mononuclear cells. ${ }^{*} \mathrm{p}<0.01$ compared with controls. MW: molecular weight.

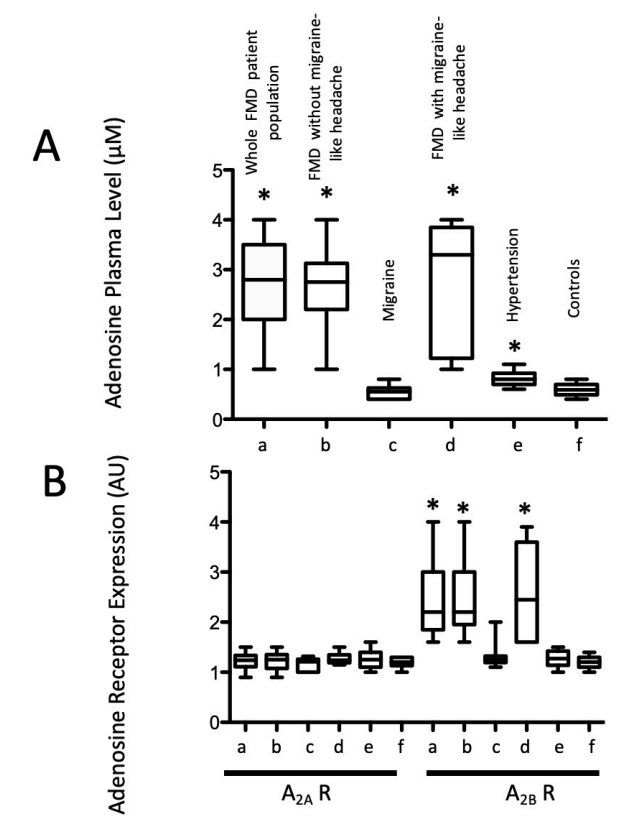

C

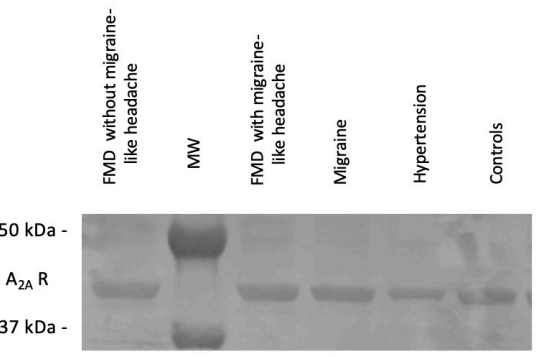

$50 \mathrm{kDa}$ -

$A_{2 B} R$

$37 \mathrm{kDa}$ -

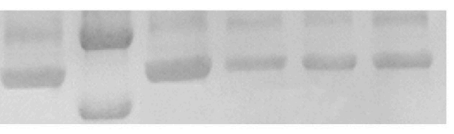

